\title{
PERAN BAHASA ARAB DALAM PENGEMBANGAN ILMU DAN PERADABAN ISLAM DI MASA DAULAH ABBASIYAH (Studi Literatur)
}

\author{
Asni Furoidah \\ IAI Al-Falah As-Sunniyyah Kencong Jember \\ (asnifuroidah148@gmail.com)
}

\begin{abstract}
This study aims to clarify the role of the Arabic language in advancing science and Islamic civilization through a library study of the history of the Arabic language a long the ages. The approach used to analyze the data of Arabic language development is historical approach combined with content analysis approach. The study has come to the conclusion that there are five important roles of Arabic language. Firstly, it served as the language of the union among the people and the Arab tribes. Secondly, Arabic preserved the richness of local Arabic cultures through all times. Thirdly, Arabic used as a media for educational and scientific study, possitioning it as the language of science and technology. Fourthly, Arabic is as a tool of communication among the people and tribes and generations. Fifthly, Arabic is accepted as a standardized language for Islamic knowledge and modern sciences.
\end{abstract}

Keywords: the role of Arabic, integration languages, conservation languages, education and study languages, communication languages, standardization languages

\section{Pendahuluan}

Bahasa Arab merupakan bahasa yang paling banyak menyandang atribut. Selain merupakan bahasa kitab suci Al-Qur'an dan hadits, bahasa Arab adalah bahasa umat Islam, bahasa resmi Perserikatan Bangsa-Bangsa (PBB), bahasa nasional lebih dari 25 negara di kawasan Timur Tengah, lugah al-dhad dan bahasa warisan sosial budaya (lughah al-turats). Jabir Qumaihah misalnya, menegaskan bahwa bahasa 
Arab merupakan bahasa yang mendapat garansi dan "proteksi ilahi" (al-himayah al-Ilahiyah), seiring dengan digunakannya sebagai "wadah ekspresi al-Qur'an" (wi'a' al-Qur'an). ${ }^{1}$ Bahasa Arab juga dipandang sebagai Bahasa yang sangat orisinil, tidak memiliki masa kanak-kanak sekaligus masa renta (lughah ashilah, laisa laha thufulah wa laisa laha syaikhukhah). ${ }^{2}$ Bahasa Arab juga merupakan fakta sejarah yang digunakan sebagai media pengajaran dan bahasa lisan masyarakat Arab sejak awal Islam hingga sekarang. ${ }^{3}$

Sebagai subsistem budaya, Bahasa Arab merupakan salah satu bahasa (rumpun) Semit (usrat al-Lughat al-Samiyyah) yang dinilai paling tua dan tetap eksis hingga sekarang. Kemampuan bahasa Arab tetap eksis hingga sekarang, antara lain disebabkan oleh posisinya sebagai bahasa pilihan Tuhan untuk kitab suci-Nya (alQur'an).

Bani Abbasiyah merupakan puncak kemajuan ilmu pengetahuan dan peradaban Islam.Sejarah mencatatbahwasalah satu faktorpenting keberhasilan pengembangan peradaban saat itu adalah karena berkembangnya gerakan penerjemahan (arabisasi) yang dimotori oleh elit penguasa, yaitu Harun al-Rasyid (786-809 M) dan al-Makmun (786-833 M). Gerakan penerjemahan itu disosialisasikan dengan ditunjang oleh adanya pusat riset dan pendidikan seperti Bait al-Hikmah dan Dar al-Hikmah. Penerjemahan karya-karya asing tidak terbatas pada ilmu-ilmu dasar, filsafat Yunani, melainkan juga mencakup matematika, astronomi, fisika, geometri, optika, musik dan kedokteran yang berasal dari Bahasa Suryani, Persia dan India.

Gerakan penerjemahan karya-karya ilmiah berbahasa asig ke dalam bahasa Arab tersebut, selain mendorong pengembangan ilmu pengetahuan dan teknologi juga berpengaruh besar terhadap wacana keilmuan Islam, baik ilmu-ilmu tradisional maupun ilmu-ilmu rasional, sehingga umat Islam tidak hanya bertindak sebagai pengalih ilmu tetapi juga sebagai penyusun, pengembang dan pembangun berbagai disiplin ilmu pengetahuan baru.

\footnotetext{
${ }^{1}$ Garansi dan proteksi tersebut berupa jaminan eksistensi dan kelestarian bahasa Arab sebagai bahasa Al-Qur'an yang otentisitas dan kelestariannya dijamin oleh Allah dalam firman-Nya berikut:

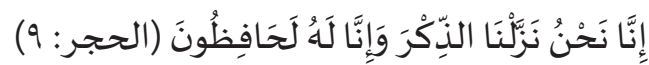
${ }^{2}$ Abd. Al-Salim Mukram, al-Lughah al-Arabiyyah fi Rihab al-Qur'an al-Karim, (Kairo: 'Alam al-Kutub, 1995), hlm. 3

${ }^{3}$ Rusydi Sulaiman, Pengantar Metodologi Studi Sejarah Peradaban Islam, (Jakarta: PT Raja Grafindo Persada, 2014), hlm.5
} 


\section{Bahasa Arab pada Masa Daulah Abbasiyah (749-1258 M)}

Dalam masa Abbasiyah, ilmu bahasa tumbuh dan berkembang dengan suburnya karena bahasa Arab yang semakin dewasa dan menjadi bahasa internasional. Disebutkan dalam The Cultural Atlas of Islam, banyaknya orang-orang non-Arab yang masuk Islam kemudian mempelajari bahasa Arab dengan sungguh-sungguh dan akhirnya memberi sumbangan besar untuk tata bahasa, sintaks, leksikografi, dan kritikisme sastra Arab.

Selama zaman Khilafah Abbasiyah bahasa Arab telah mencapai kedudukan sebagai bahasa ilmu pengetahuan yang dipergunakan untuk menerjemahkan buku-buku ilmu pengetahuan dan filsafat Yunani, sehingga mendorong ke arah perubahan dan perkembangan ilmu kaum muslimin, demikian pula pada zaman berikutnya bukubuku hasil terjemahan tersebut beserta tafsiran dan penjelasannya yang dibuat oleh para ilmuwan muslim merupakan buku-buku pegangan (references) yang sangat diperlukan oleh dunia Barat pada zaman kebangkitan dunia Kristen di Barat yang dihadapkan kepada kebutuhan untuk memahami soal-soal keagamaan yang tidak cukup hanya bersifat dogmatis semata-mata, akan tetapi perlu pemahaman secara rasional.

Pada zaman ini, pendidikan Islam sudah mengalami perkembangan melebihi dari zaman-zaman sebelumnya. Pergaulan antar bangsa semakin menguat. Islam telah bertapak di tiga benua: Asia, Afrika dan Eropa. Berbagai bangsa telah menjadi penguat Islam. Pada masa ini semakin intensiflah kontak peradaban. Dalam kontak peradaban ini tentu kaum muslimin telah semakin mengenal peradabanperadaban yang telah maju di daerah-daerah yang ditaklukkan seperti negara Syam, Irak, Persia, Mesir, Afrika, Andalusia, dan sampai ke bagian Timur wilayah Transsoksiana dan juga sampai ke India. Kontak peradaban inilah merupakan cikal bakal bagi kemajuan ilmu pengetahuan di dunia Islam.

\section{Bahasa Arab dan Peradaban Islam}

Terlepas dari ilmu apa yang pertama kali lahir dari "rahim dunia Islam", dalam perkembangan selanjutnya, pada masa Khalifah Malik ibn Marwân, bahasa Arab diposisikan sebagai bahasa negara (daulah Umayyah), khususnya sebagai bahasa resmi dan bahasa administrasi pemerintahan. Meskipun Arabisasi ini memang agak bernuansa politis, karena Bani Umayyah tergolong memiliki "fanatisme yang kuat" (ta'ashshub qawiy) terhadap kesukuan dan kearabannya, dampaknya cukup luas 
dan signifikan. Pengaruh bahasa Persia, Qibtia, dan bahasa Romawi sebagai bahasa administrasi di masa lalu (sebelum khilafah Umawiyah) kemudian digantikan oleh bahasa Arab. ${ }^{4}$

Bangsa Arab memang dapat dianggap bangsa "pemenang bukan pecundang". Karena itu, ketika berbagai istilah dalam bidang administrasi, ekonomi, sosial, dan politik didominasi, terutama, oleh bahasa Romawi dan Persia, Khalifah Abdul Malik bin Marwan menemukan momentumnya yang tepat untuk memulai arabisasi Negara (ta'rîb al-dawlah), yang pada gilirannya diikuti dengan arabisasi administrasi pemerintahan (ta'rîb al-dawâwîn), mata uang, bahkan arabisasi budaya. Dari gerakan arabisasi inilah, cikal bakal teoritisasi dan dinamisasi ilmu-ilmu dalam bahasa Arab itu dimulai. ${ }^{5}$

Implikasinya lebih jauh adalah bahwa karya-karya sastra (sya'ir/puisi, natsr/ prosa) yang bernuansa kearaban banyak bermunculan. Romantisme "kejayaan bahasa Arab era Jahiliyah" kembali menemukan bentuknya. Mata uang resmi diarabkan (dalam bentuk dinâr dan dirhâm) yang semula berbahasa Persia atau Romawi-Yunani. Berbagai transaksi sosial-ekonomi dihampir seluruh wilayah dinasti Umawi juga menggunakan bahasa Arab. Dengan demikian, pada masa itu, bahasa Arab tidak sekadar bahasa agama, melainkan juga sebagai bahasa negara: bahasa administrasi, birokrasi, diplomasi, dan bahasa transaksi sosial ekonomi. ${ }^{6} \mathrm{Di}$

${ }^{4}$ Menarik dicatat bahwa ketika bangsa Arab menaklukkan negeri-negeri yang dekat atau yang jauh di luar Jazirah Arabia, mereka tidak mencampuri bahasa dan kebudayaan bangsabangsa yang mereka taklukkan. Karena itu, pada masa awal sejarah Islam, bahasa resmi negara adalah Yunani dan Persia, tetapi dalam perjalanan waktu, dirasakan perlunya peralihan ke dalam bahasa Arab. Penerjemahan pun diubah, dari Suryani ke dalam bahasa Arab. Lebih lanjut lihat, C.A. Qadir, Filsafat dan Ilmu Pengetahuan dalam Islam, terj. dari Philosophy and Science in the Islamic World oleh Hasan Basari (Jakarta: Obor Indonesia, 1989), hlm. 37

${ }^{5}$ Jibran Mas'ud, al-'Arabiyyah al-Fushhâ: Sya'latun lâ Tantha'i' (Beirut: Bait al-Hikmah, 2001),hlm. 30-31

${ }^{6}$ Uraian lebih detail, lihat Husain Hallâq, Târîkh al-Hadhârah al-Islâmiyyah (Kairo: Dâr al-Kutub al-Islâmiyyah, 1988). Di antara kisah sukses dinasti Umayyah yang berpusat di Damaskus (Suriah) adalah Arabisasi tersebut. Hal ini paradoks dengan bahasa yang digunakan Nabi `Isa yang pernah hidup di kawasan Palestina-Suriah (sekarang). Nabi `Isa ternyata menggunakan tiga bahasa dalam hidupnya: bahasa Ibarani untuk bahasa kitab suci (Injil), bahasa Yunani untuk pemikiran, dan bahasa Aramea untuk percakapan sehari-hari. Perlu ditegaskan bahwa selama hampir 4 abad kawasan Suriah telah terhelenisasikan atau terromawikan, sehingga bahasa Yunani telah menjadi bahasa akademik. Uraian mengenai hal ini, lihat Nurcholish Madjid, "Orientasi dan Metodologi Studi Islam Masa Depan”, dalam Jauhar, Jurnal PPs. IAIN Jakarta, Edisi I, Desember 2000. 
antara dîwân (semacan kantor kementerian) yang diarabisasikan ketika itu adalah Kementerian Perpajakan, Kementerian Pos dan Telekomunikasi, dan Kementerian Keuangan. Berbagai arabisasi istilah, ungkapan, dan tradisi (budaya) juga terjadi dalam berbagai instansi pemerintah lainnya. ${ }^{7}$ Atas dasar itu, dapat ditegaskan bahwa gerakan arabisasi, yang semula merupakan kebijakan politik, ternyata menjadi cikal bakal gerakan intelektual, gerakan kultural, pengembangan ilmu pengetahuan dan peradaban.

Ketika dinasti Abbasiyah berkuasa, menggantikan dinasti Umayyah, orientasi dan tradisi keilmuan mendapat ruang dan momentumnya yang relevan dan signifikan. Bersamaan dengan itu, atas kebijakan khalifah Hârûn al-Rasyîd (786-809 M) dan terutama al-Ma'mûn (813-833 M), gerakan “intelektualisasi” berjalan mulus dan memperlihatkan kesuksesan yang luar biasa. Proses intelektualisasi dan sivilisasi (pemeradaban) umat Islam ini, tentu saja tidak dapat dipisahkan dari pergumulan dan interaksi sosial budaya dan pemikiran antara umat Islam dengan berbagai bangsa lain, utamanya bangsa-bangsa bekas dominasi Romawi (seperti Suriah, Turki, Palestina, Yordania) dan Persia yang memang meninggalkan khazanah keilmuan di berbagai bidang keilmuan. Yang menarik dalam konteks ini adalah bahwa sang khalifah yang menginstruksikan gerakan penerjemahan besar-besaran berbagai karya filosof Yunani dan ilmuwan Persia dan India ke dalam bahasa Arab. ${ }^{8}$

Di antara buku yang diarabkan saat itu adalah al-Tasyrîh (Pembedahan) karya Jalinus, al-Handasah (Arsitektur) karya Plato, al-Majesti karya Ptolemios, dan al-Samấ wa al-'Âlam karya Aristoteles. Kolaborasi ulama dan umara' terbukti membuahkan proses dan dinamika keilmuan yang sangat pesat sehingga dalam waktu yang relatif singkat kemajuan peradaban Islam dalam berbagai bidang dapat diwujudkan. Dialektika pengetahuan dan kekuasaan ini ditopang oleh teologi rasional negara (Mu'tazilah) yang berpengaruh besar terhadap dinamisasi pengembangan ilmu dan peradaban Islam. ${ }^{9}$

${ }^{7}$ Yûsuf al-'Isysy, al-Dawlah al-Umawiyyah wa al-Ahdâts al-Târîkhiyyah al-latî Sabaqathâ wa Mahhadât lahâ ibtidân min Fitnah 'Utsmân (Damaskus: Dâr al-Fikr, 1989), cet. 5, hlm. 212

${ }^{8}$ Antusiasme penerjemahan berbagai karya ilmiah pada masa Harun al-Rasyîd (786-809) tampaknya dispiriti oleh salah seorang menteri Hârun al-Rasyîd, yaitu Yahya al-Barmakî (w. 805), yang memang menaruh perhatian terhadap studi filsafat dan logika. Dengan kata lain, gerakan intelektual dalam bentuk penerjemahan karya-karya penting dari bahasa Yunani, Persia maupun Suryani dan India, ke dalam bahasa Arab justru dimotori oleh penguasa. Lihat, C.A. Qadir, op. cit., hlm. 36

${ }^{9}$ Kajian mengenai ralasi dan dialektika pengetahuan dan kekuasaan (jadaliyyah alma'rifah wa al-sulthah) relatif kurang populer, padahal dialektika itu sangat menentukan orientasi 
Gerakan penerjemahan tersebut tidak hanya melibatkan sumber daya manusia (SDM) dari kalangan umat Islam saja, melainkan juga melibatkan atau ada semacam usaha "menyewa" atau memanfaatkan para penerjemah dari kalangan Nasrani, seperti Hunain ibn Ishâq (808-873 M), dan Ishaq ibn Hunain untuk menekuni dan mendedikasikan keahliannya dalam menerjemahkan karya-karya dari bahasa Yunani dan Suryani ke dalam bahasa Arab. ${ }^{10}$ Kerjasama akademik lintas agama dan budaya ini membuktikan bahwa Islam dan peradabannya memang terbuka dan bisa bekerjasama secara sinergis dengan siapapun, termasuk ilmuwan Yahudi, yang pada umumnya menguasai bahasa Suryani. Hal ini sekaligus menjadi isyarat kuat bahwa untuk bisa maju dalam bidang ilmu pengatahuan dan peradaban, umat Islam harus terbuka dan bersedia melakukan kerjasama atau kemitraan keilmuan dengan siapapun.

Pendirian Bait al-Hikmah oleh al-Makmun menjadikan bahasa Arab sebagai bahasa politik sekaligus sebagai bahasa pendidikan, ilmu pengetahuan, dan kebudayaan. Dengan kata lain, wacana keilmuan dalam berbagai bidang (filsafat, teologi, tasawuf, bahasa, fiqh, kedokteran, kimia, optika, geografi, musik, matematika, Aljabar, Aritmatika, dan sebagainya) diekspresikan dan dikembangkan dengan menggunakan bahasa Arab, meskipun pengembang dan perumusnya bukan orang Arab.

Posisi bahasa Arab sebagai bahasa ilmu pengetahuan Islam, bahasa pendidikan, dan kebudayaan pada masa keemasan Islam tersebut dipandang penting sebagai "prestasi ganda", yaitu prestasi Islam dan [bahasa] Arab. Karena itu, banyak penulis yang kemudian menyandingkan kata "Islam dan Arab" dalam berbagai judul karya, seperti al-Wâfî fî Târîkh al-'Ulûm 'inda al- 'Arab karya 'Abduh al-Hilwu dan Bahzad Jâbir, Târikh al-Falsafah al-'Arabiyyah karya Jamîl Shalîba, Tajalliyât al-Falsafah al'Arabiyyah karya Abû Ya'rib al-Marzûqî, dan sebagainya.

Prestasi tersebut disebabkan oleh beberapa faktor. Di antaranya adalah faktor politik, yaitu adanya political will dari penguasa yang sangat haus dan antusias terhadap pengembangan iptek saat itu untuk mengembangkan tradisi ilmiah dan pengembangan insitusi pendidikan dan ilmu. Yang sering menjadi bahan kajian adalah hubungan agama dan politik, bukan pengatahuan dan kekuasaan atau sinergi ulama dan umara. Lebih lanjut lihat, 'Abd al-Majid al-Shaghir, al-Ma'rifah wa al-Sulthah fî al-Tajribah al-Islâmiyyah (Kairo: al-Hai'ah al-Mishriyyah al-'Ammah, 2010).

${ }^{10}$ Pembahasan mengenai hal tersebut, lihat 'Ali 'Abdullah al-Difầ, Min Rawâ'i' wa Ishâmât al-Hadhârah al-Islâmiyyah (Beirut: Muassasah al-Risâlah, 1999). Bandingkan dengan Mehdi Nakosteen, Kontribusi Islam atas Dunia Intelektual Barat, terjemahan, (Surabaya: Risalah Gusti, 1996). 
sistem pendidikan yang berorientasi kepada intelektualiasi sekaligus spiritualisasi. Kedua, faktor ekonomi berupa kemakmuran dan kesejahteraan rakyat di bidang ekonomi, sehingga sebagian besar mereka menekuni bidang keilmuan secara "khusyuk": serius dan produktif. Ketiga, faktor bahasa Arab yang memang sangat akomodatif untuk dijadikan sebagai media reproduksi pemikiran dan karya-karya ilmiah para filosof dan ilmuwan Muslim. Meskipun al-Khalîl ibn Ahmad, Sîbawaih, Ibn Sînâ, al-Fârâbî, al- Râzî, Ibn Miskawaih, al-Ghazâlî, Ibn Rusyd, Ibn Mâlik dan sebagainya bukan orang Arab asli, mereka dengan penuh ekspresi dan apresiasi menjadikan bahasa Arab sebagai bahasa ilmu. Madrasah Nizhamiyyah di Persia, tempat al-Ghazâlî digurubesar-kan, Madrasah al-Ayyubiyyah, Pusat-pusat Studi di Harran dan Jundisyapur (Persia) serta al-Azhar di Kairo juga menjadikan bahasa Arab sebagai bahasa akademik: bahasa studi, pendidikan, dan kebudayaan mereka. Keempat, faktor ideologi dan mazhab teologi negara yang rasional (Mu'tazilah) juga turut mendinamisasikan pengembangan ilmu dan peradaban. Istana pada masa itu bukan sekadar singgasana, tetapi sekaligus menjadi pusat diskusi, perdebatan akademik, dan sebagainya.

Posisi strategis bahasa Arab sebagai bahasa pendidikan, kebudayaan, politik dan sebagainya dalam kehidupan sehari-hari pada masa kejayaan Islam tersebut, tidak dapat dipisahkan dari beberapa faktor penting. Diantaranya: pertama, faktor ideologis; bahwa bahasa Arab memang sudah "mengkristal" dengan agama Islam yang dianut oleh pemeluknya. Kedua, faktor doktrinal; bahwa alQur'an yang berbahasa Arab itu sangat menekankan umatnya mencari dan mengembangkan ilmu pengetahuan sehingga umat Islam terpacu untuk memahami dan mengaktualisasikan ajaran Islam yang tertuang dalam teks Arab alQur'an dan al-Sunnah. Ketiga, faktor linguistik; bahwa bahasa Arab-hingga kini tetap memperlihatkan sebagai bahasa fushhâ yang berkembang dinamis, sanggup mengikuti perkembangan zaman disebabkan oleh berbagai keunggulan morfologis, sintaksis, semantik dan sosiologis. Keempat, faktor politik; dukungan penguasa dan rakyat yang multilateral dan multi-etnis dari Andalusia (Spanyol) di Barat dan Persia di Timur memungkinkan bahasa Arab berkembang dan tersosialisasi dengan sangat efektif dalam berbagai lapisan masyarakat. ${ }^{11}$ Ekspansi politik Islam, terutama pada masa Umayyah dan Abbâsiyah tampak berimplikasi pada proses Islamisasi serta arabisasi bahasa. Penguasa, ulama, dan partisipasi publik yang plural dan multikultural dalam pengembangan sistem pendidikan Islam membuat

11 Abbâs Mahjûb, Musykilât Ta'lîm al-Lughah al-'Arabiyyah: Hulûl Nazhariyyah wa Tathbîqiyyah (Doha: Dâr al-Tsaqâfah, 1986), hlm. 19-26 
kemajuan ilmu pengetahuan dan peradaban Islam menjadi semakin progresif.

\section{Peran Bahasa Arab dalam Pengembangan Ilmu dan Peradaban Islam}

Sejarah perkembangan bahasa dan sastra Arab merupakan suatu proses yang paling mengagumkan dalam perkembangan bahasa-bahasa utama dunia. Bahasa ini memiliki perkembangan dan kelestariannya yang sangat baik. Dalam waktu yang singkat, bahasa Arab berhasil menduduki tempat yang terhormat di kawasan yang amat luas di Timur Tengah, Afrika Utara, dan untuk jangka waktu yang singkat di Spanyol dan Sicylia walaupun tidak sedikit masalah dan tantangan yang menghadang kemajuannya.

Puncak kemajuan ilmu pengetahuan dan peradaban Islam terjadi pada masa pemerintahan Bani 'Abbâsiyah. Sejarah mencatat bahwa salah satu faktor penting keberhasilan pengembangan peradaban saat itu adalah karena berkembangnya gerakan penerjemahan (arabisasi) yang dimotori oleh elit penguasa, yaitu Hârun al-Rasyîd (786-809 M) dan al-Makmun (786-833 M). Gerakan penerjemahan itu disosialisasikan dengan ditunjang oleh adanya pusat riset dan pendidikan seperti Bait al-Hikmah dan Dâr al-Hikmah. Penerjemahan karya-karya asing tidak terbatas pada ilmu-ilmu dasar, filsafat Yunani, melainkan juga mencakup matematika, astronomi, fisika, geometeri, optika, musik, dan kedokteran yang berasal dari bahasa Suryani, Persia dan India.Gerakan penerjemahan karya-karya ilmiah berbahasa asing ke dalam ba-hasa Arab tersebut, selain mendorong pengembangan ilmu pengetahuan dan teknologi, juga berpengaruh besar terhadap wacana keilmuan Islam, baik ilmu-ilmu tradisional maupun ilmu-ilmu rasional, sehingga umat Islam tidak hanya bertindak sebagai pengalih ilmu tetapi juga sebagai penyusun, pengembang, dan pembangun berbagai disiplin ilmu pengetahuan baru.

Fakta-fakta historis dan sosial intelektual yang diuraikan di atas memperlihatkan kepada kita bahwa bahasa Arab berperan penting terhadap kemajuan ilmu pengetahuan dan peradaban Islam diantaranya:

1. Bahasa Integrasi

2. Bahasa Konservasi

3. Bahasa Edukasi dan Studi

4. Bahasa Komunikasi

5. Bahasa Standarisasi 


\section{Aktualisasi Peran Bahasa Arab dalam Pengembangan Ilmu dan Peradaban}

Dari uraian terdahulu dapat ditegaskan bahwa warisan intelektual Yunani, khususnya di bidang filsafat yang cukup kaya dan subur itu, ternyata banyak menarik perhatian umat Islam, terutama para mutakallimûn (teolog) yang banyak dihadapkan kepada perdebatan teologis dan kebutuhan untuk menggunakan logika dan filsafat dalam berargumentasi. Khazanah Hellenistik yang pernah dominan cukup lama di berbagai wilayah Asia Barat, Asia Kecil, dan sebagian Afrika mulai menggugah para ilmuwan Islam untuk mengenal dan mempelajarinya. Pengaruh Hellenisasi telah dimulai pada masa pertengahan dinasti Umayyah dan puncaknya pada masa Abbasiyah. ${ }^{12}$ Pengaruh tersebut tampak pada pendirian Pusat Observatori Astronomi di Damaskus, Suriah sekitar 700 M. Dengan kata lain, cikal bakal tradisi ilmiah dan penerjemahan karya-karya dari berbagai bahasa asing ke dalam bahasa Arab mulai berkembang pada masa Bani Umayyah.

Puncak kemajuan ilmu pengetahuan dan peradaban Islam terjadi pada masa pemerintahan Bani 'Abbâsiyah. Sejarah mencatat bahwa salah satu faktor penting keberhasilan pengembangan peradaban saat itu adalah karena berkembangnya gerakan penerjemahan (arabisasi) yang dimotori oleh elit penguasa, yaitu Hârun al-Rasyîd (786-809 M) dan al-Makmun (786-833 M). Gerakan penerjemahan itu disosialisasikan dengan ditunjang oleh adanya pusat riset dan pendidikan seperti Bait al-Hikmah dan Dâr al-Hikmah. Penerjemahan karya-karya asing tidak terbatas pada ilmu-ilmu dasar, filsafat Yunani, melainkan juga mencakup matematika, astronomi, fisika, geometeri, optika, musik, dan kedokteran yang berasal dari bahasa Suryani, Persia dan India.

Gerakan penerjemahan karya-karya ilmiah berbahasa asing ke dalam bahasa Arab tersebut, selain mendorong pengembangan ilmu pengetahuan dan teknologi, juga berpengaruh besar terhadap wacana keilmuan Islam, baik ilmu-ilmu tradisional maupun ilmu-ilmu rasional, sehingga umat Islam tidak hanya bertindak sebagai pengalih ilmu tetapi juga sebagai penyusun, pengembang, dan pembangun berbagai disiplin ilmu pengetahuan baru. Dalam konteks ini, setidaknya ada tiga tahapan perkembangan peradaban Islam. Pertama, munculnya gerakan penerjemahan dan pemahaman berbagai karya asing ke dalam bahasa Arab. Kedua, implikasi dari gerakan ini, adalah lahirnya fase kreasi ilmu (marhalah al-ibdâ' al-'ilmî́). Bangsa Arab (Muslim) tidak lagi sekadar menerjemahkan tetapi juga memproduksi: menulis

${ }^{12}$ Pengaruh tersebut tampak dalam perkembangan dan pengembangan ilmu di dunia Islam. Lihat 'Umar al-Taumi al-Syaibani, "Ishâmât al-Muslimîn fi al-'Ulûm”, dalam Jurnal al-Da'wah al-Islâmiyyah, Tripoli-Libia, Edisi IX, 1992, hlm. 15-17 
dan mengembangkan ilmu melalui berbagai penelitian dan pengembangan. Ketiga, berkembangnya fase inovasi dan aplikasi ilmu pengetahuan (marhalah al-ibtikâr wa al-tathbîq al-'ilmî̉) sehingga melahirkan kemajuan teknologi dan karya-karya seni dan budaya. Ilmu dalam Islam ditransformasikan dan dikontekstualisasikan dengan kehidupan nyata. Semua tahapan dan fase perkembangan itu tidak terlepas dari peran bahasa Arab sebagai bahasa ilmu dan teknologi.

Ketika peradaban Islam di Spanyol dan Sicilia mengalami kemajuan, terutama di bawah pengaruh Ibn Rusyd (1126-1198 M), Barat masih terlelap dalam kegelapan ilmu. Setelah menyadari ketertidurannya, Barat lalu bangkit, kemudian melakukan gerakan penerjemahan seperti pernah dilakukan oleh umat Islam. Pengaruh Averoisme di Barat ternyata membawa mereka bangkit dari ketertinggalannya, sehingga mereka berhasil mencapai renaisance (tanwîr wa nahdhah), dengan revolusi industri sebagai titik awalnya. Demikian pula restorasi dan reformasi di Jepang setelah kalah dalam Perang Dunia II juga dimulai dengan gerakan penerjemahan besar-besaran terhadap karya-karya ilmuwan Barat dari bahasa Inggris ke dalam bahasa Jepang. Jadi, penerjemahan, baik sebagai ilmu maupun praktik atau profesi, mempunyai kontribusi yang besar dalam pengembangan ilmu pengetahuan, pendidikan dan peradaban umat manusia sepanjang sejarah. Peradaban Islam Indonesia modern, kalau boleh disebut seperti itu, tampaknya belum melalui tahapan perkembangan dan pengembangan ilmu yang pernah dilalui oleh umat Islam di masa lalu ketika hendak mencapai puncak kejayaannya.

Setelah Bagdad jatuh pada tahun 1258 M akibat dihancurkan oleh tentara Mongol, dan dunia Islam mengalami kemunduran, posisi bahasa Arab pun mengalami pergeseran dari bahasa akademik ilmiah menjadi bahasa yang cenderung lebih bernuansa religius (bahasa agama, bahasa spritual). Karyakarya intelektual dalam berbagai bidang tidak begitu banyak lagi ditemukan dalam bahasa Arab. Bahasa Arab seakan menjadi "loyo" karena ketidakberdayaan politik dan ekonomi umat Islam vis a vis hegemoni Barat yang maju secara sains dan ekonomi. Perhatian umat Islam pada saat itu cenderung ditujukan kepada perebutan kekuasaan di satu pihak, dan di pihak lain, sebagian cenderung memilih lelaki sufistik atau "asyîq-ma'syûq" bertarekat atau lebih mementingkan urusan ukhrawi dengan "berdzikir" daripada mengembangkan ilmu pengatahuan dan peradaban.

Meskipun demikian, menarik dicatat bahwa dalam abad ke-18 dan 19, beberapa ulama Jawi, seperti Syekh Nawawi al-Bantani, Syekh Mahfuzh al-Tirmasi, Syekh Ahmad Khatib al-Minangkabawi, Syekh Syamsuddin al-Sumatrani dan sebagainya, 
yang bermukim di Haramayn (Mekkah dan Madinah), termasuk KH. Hasyim Asy'ari, banyak menelurkan karya-karya bermutu yang ditulis dalam bahasa Arab. Setelah masa "keemasan ulama Jawi" tersebut, karya-karya ulama Indonesia yang ditulis dalam bahasa Arab mengalami penurunan. Hal ini menunjukkan bahwa aktualisasi peran bahasa Arab dalam pengembangan ilmu dan peradaban perlu direvitalisasi dan dikembangkan di era modern ini.

Menurut penulis, ada sejumlah faktor yang menjadi penyebab "kemandulan akademik" dalam berkarya dengan menggunakan bahasa Arab. Di antaranya adalah ketidakmampuan sebagian ulama dalam mengekspresikan karya mereka dengan bahasa Arab (karena mungkin bahasa Arab dinilai sulit dan berbelitbelit), penghargaan terhadap karya ilmiah berbahasa Arab tergolong minim, tradisi dan kondisi ilmiah tidak kondusif, sistem pendidikan dan pengajaran bahasa Arab di berbagai institusi pendidikan Islam kurang menunjang, dan rendahkan kesadaran "promosi" karya intelektual anak bangsa ini ke dunia Arab; bahkan di kalangan bangsa-bangsa Arab sendiri terdapat kecenderungan yang menguat terhadap penggunaan bahasa Arab 'âmiyyah (pasaran, bukan bahasa formal) belakangan ini.

Fakta-fakta historis dan sosial intelektual yang diuraikan di atas memperlihatkan kepada kita bahwa bahasa Arab pada awal Islam hingga puncak kemajuan ilmu pengetahuan dan peradaban Islam memainkan setidak-tidaknya lima peran penting. Pertama, bahasa Arab berperan sebagai bahasa integrasi. Sejarah menunjukkan bahwa mayoritas bangsa-bangsa yang ditaklukkan Islam semula bukan berbahasa Arab. Akan tetapi, dalam perkembangannya warga masyarakat yang baru dibebaskan oleh penguasa Islam ini, bahasa Arab mampu menyatukan banyak suku bangsa dan budaya. Peran integrasi ini menjadi semakin solid dan kuat terutama setelah khalifah Abdul Malik ibn Marwan melakukan gerakan arabisasi dan menjadi bahasa Arab sebagai bahasa negara dan administrasi pemerintahan. Peran integratif bahasa Arab ini ditopang oleh ajaran Islam yang mengedepan integrasi dan kesatuan akidah, kesatuan ukhuwah, kesatuan akhlak, kesatuan pemikiran, kesatuan hukum, dan kesatuan budaya. Kedua, bahasa Arab berperan sebagai bahasa konservasi. Ketika Islam berkembang ke luar Jazirah Arabia, kebutuhan umat Islam untuk dapat mengakses dan memahami sumber ajaran Islam (alQur'an) tentu semakin mendesak. Pada saat sama, ketika sebagian umat Islam nonArab banyak melakukan lahn, para ulama bahasa Arab merasa perlu merumuskan ilmu-ilmu dasar bahasa Arab (nahwu dan sharaf). Dengan diformulasikannya ilmu ini, bahasa Arab tidak hanya berperan menjaga kelestarian (konservasi) kekayaaan bahasa dan budaya Arab itu sendiri dari masa ke masa, termasuk konservasi turats 
(warisan atau khazanah intelektual Arab dan Islam), tetapi juga menjaga otentisitas al-Qur'an. Karena itu, formulasi ilmu tersebut juga dibarengi dengan pemberian tanda baca (titik-titik) dan harakat (fathah, dhammah, kasrah, dan sukûn) alQur'an. Jadi, terdapat hubungan simbiosis-mutualisme ('alâqah mutabâdilah wa mutalâzimah) antara Islam dan bahasa Arab, antara agama dan bahasa atau antara doktrin dan media komunikasi sehingga kedua berkembang secara saling mendukung. Tanpa spirit Islam yang mengharuskan umatnya cerdas dalam "iqra'”, mustahil bahasa Arab berkembang maju.

Ketiga, bahasa Arab berperan sebagai bahasa edukasi dan studi. Ketika Islam mencapai kemajuannya, bahasa Arab kemudian memainkan peran sebagai bahasa pendidikan, pembelajaran dan penelitian ilmiah di hampir semua lapisan masyarakat Arab sehingga bahasa Arab kemudian menjadi bahasa ilmu pengetahuan dan teknologi. Hal ini ditunjang oleh kontribusi kebijakan politik dan finansial yang sangat besar dari elit penguasa, terutama al-Makmun, kepada para peneliti dan pengembang ilmu. Sedemikian besar dukungan kekuasan terhadap penerjemahan, penelitian, dan pengembangan ilmu, al-Makmun yang mempercayakan pengembangan lembaga riset Bait al-Hikmah kepada Hunain ibn Ishâq menilai karya hasil terjemahannya dari bahasa Yunani dan Suryani ke dalam bahasa Arab itu dengan insentif berupa emas seberat hasil karya terjemahannya. Artinya, jika dia berhasil menerjemahan karya asing ke dalam bahasa Arab seberat $1 \mathrm{~kg}$, maka insentifnya pun berupa $1 \mathrm{~kg}$ emas. Dalam waktu bersamaan, berbagai lembaga pendidikan yang sudah berkembang di wilayah-wilayah Islam seperti madrasah Jundisapur, Herat, Harran, Iskandaria, Antakia, dan sebagainya menjadikan bahasa Arab sebagai bahasa edukasi dan studi, bahasa penelitian, dan pengembangan ilmu. Bahkan, menurut Ira M. Lapidus, budaya (kultur) bahasa Arab merupakan produk dari tiga hal, yaitu produk masyarakat perkotaan kelas menengah yang konsen dengan keilmuan Islam, produk loyalitas kesukuan bangsa Arab, dan produk penguasa (istana). ${ }^{13}$

Keempat, bahasa Arab berperan sebagai bahasa komunikasi lintas suku bangsa dan generasi yang mempercepat proses transmisi nilai-nilai Islam dan nilai-nilai sosial kemanusiaan di kalangan masyarakat Arab. Seperti karakter bangsa Arab pada umumnya, bahasa Arab merupakan bahasa yang terbuka. Sebagai bahasa terbuka, bahasa Arab sejak awal memperlihatkan kemampuannya beradaptasi dan menerima perubahan, termasuk mengadopsi bahasabahasa Asing. Dalam al-Qur'an,

${ }^{13}$ Ira M. Lapidus, Sejarah Sosial Umat Islam, terj. Ghufron M. Mas'adi (Jakarta: Rajawali Press, 1999), hlm. 138-139 
dapat dijumpai sejumlah kata yang berasal dari bahasa lain, seperti: 'irdaus, zanzabîl, kafûr, istibrâq, qamtharîr, salsabîl, dan sebagainya. Di era modern ini, bahasa Arab juga memperlihatkan perannya sebagai bahasa komunikasi dalam berbagai bidang, terutama politik, ekonomi, dan sosial budaya, termasuk media massa, baik di dunia nyata maupun dunia maya. Selain itu, sebagai bahasa komunikasi akademik, terutama di kalangan akademisi Arab, banyak sekali karya ilmiah dipublikasikan melalui berbagai media, juga menjadikan bahasa ini semakin berkembang, antara lain, dengan banyaknya mufradat dan istilah baru dalam bahasa Arab. ${ }^{14}$

Kelima, bahasa Arab berperan sebagai bahasa standarisasi di bidang ilmu-ilmu keislaman dan lainnya. Hal ini terbukti dengan dirintiskan penulisan kamus bahasa Arab. Menurut catatan sejarah, mu'jam al-Ain karya al-Khalil ibn Ahmad (100$170 \mathrm{H}$ ) adalah kamus pertama di dunia Islam. Kamus ini sudah memiliki sistem dan metode ilmiah yang cukup solid. Dari kamus ini, kelak menginspirasi lahirnya aneka kamus dalam bahasa Arab, seperti Maqâyîs al- Lughah karya Ibn Faris, Lîsan al-Arab karya Ibn Manzhur, hingga aneka kamus istilah dalam berbagai bidang keilmuan yang terutama diprakarsai dan dikembangkan oleh Maktabah Lubnan di Beirut.

Spesialisasi kamus dalam bahasa Arab mulai berkembang sejak tahun 1970-an, setelah beberapa negara di Timur Tengah mulai banyak bergumul dengan [atau terpengaruh oleh dinamika leksikologi] Barat, utamanya dalam rangka studi dan eksplorasi minyak, sehingga proses transformasi teknologi pun terjadi dan dengan sendirinya usaha untuk melakukan "Arabisasi" istilah-istilah teknologi pun berkembang. Spesialisasi itu, antara lain, terlihat pada terbitnya beberapa kamus sebagai berikut:

- Ahmad Syafîq al-Khathîb, Mu'jam al-Mushthalahât al-'Ilmiyyah wa al- Fanniyah wa al-Handasiyyah, Beirût: Maktabah Lubnân, Cet. I, 1971 (Cet. VI, 1991).

- Majdy Wahbah, Mu'jam al-'Ibârât al-Siyâsiyyah al-Hadîtsah, Beirût: Maktabah Lubnân, 1978.

- Ahmad Zaky Badawî, Mu'jam Mushthalahât al-'Ulûm al-Ijtimâ'iyyah, Bairût: Maktabah Lubnân, 1982.

- Nabîh Ghattâs, Mu'jam Mushthalahât al-Iqtishâd wa al-Mâl wa Idârah al-A'mâl, Beirût: Maktabah Lubnân, 1985.

\footnotetext{
${ }^{14}$ Mahmud Fahmi Hijazi, al-Lughah al-'Arabiyyah fî al-'Ashr al-Hadîts: Qadhâyâ wa Musykilât (Kairo: Dar Quba', 1998), hlm. 137-138
} 
- Muhammad Mushthafâ Zaidân, Mu'jam al-Mushthalahât al-Nafsiyyah wa alTarbawiyyah, Beirût: Dâr al-Syurûq, 1984.

- Nabîh Ghattâs, et.al., Mu'jam al-Idârah, Beirût: Maktabah Lubnân, 1983.

- Muhammad 'Alî al-Khûlî, Mu'jam 'Ilm al-Lughah al-Tathbîqî,, Beirût: Maktabah Lubnân, 1986.

- Hârits Sulaimân al-Fâruqî, al-Mu'jam al-Qanunî, Beirût: Maktabah Lubnân, Edisi III, 1991.

- Jamîl Shalîbâ, al-Mu'jam al-Falsafî, dua jilid, Beirût: Dâr al-Kitâb al-Lubnânî, 1982.

- Sumûhî Fawqa al-'Adah, Mu'jam al-Diblumâsiyyah wa al-Syu'ûn al- Dawliyyah, Beirût: Maktabah Lubnân, tt.

Agar kelima peran bahasa Arab dapat diaktualisasikan, menurut penulis, perlu adanya terobosan-terobosan inovatif baik dalam "pengilmuan" bahasa Arab maupun pembelajarannya. Misalnya saja, orientasi pembelajaran bahasa Arab perlu diubah, terutama di dalam sistem pendidikan pesantren dan madrasah (kemudian di perguruan tinggi), dari sekadar sebagai proses spiritualisasi atau untuk membaca "kitab kuning" menjadi proses intelektualisasi dan profesionalisasi. Bahasa Arab tidak sekadar diposisikan sebagai alat untuk memahami melainkan juga media untuk komunikasi, reproduksi keilmuan, dan diplomasi kebudayaan. Strateginya adalah dengan pendekatan politik dan akademik.

Dalam konteks itu, kita harus bisa meyakinkan pemerintah, utamanya Kementerian Agama dan Kementerian Pendidikan dan Kebudayaan agar mendeklarasikan dan memberikan maklumat moral bahwa bahasa Arab itu sangat penting dan perlu dipelajari, baik oleh umat Islam maupun yang lain. Dengan begitu, bahasa Arab bukan lagi "bahasa milik orang Islam" dan hanya dikaji di lembaga-lembaga pendidikan Islam. Aneka kegiatan diplomasi dan promosi (pariwisata, peluang investasi, kerjasama ekonomi, dan sebagainya) dengan berbagai negara Timur Tengah perlu didorong sedemikian rupa sehingga posisi tawar bahasa Arab di Indonesia semakin kuat dan menarik minat banyak kalangan.

Selain itu, kesadaran umat Islam juga harus dibangkitkan, melalui berbagai lembaga pendidikan dan media massa bahwa belajar bahasa Arab itu tidak sekadar untuk memahami Islam, melainkan juga untuk memahami ilmu pengetahuan, yang kini sudah mulai banyak ditulis dalam bahasa Arab. Selanjutnya, perlu dipikirkan 
bersama adanya upaya pencitraan dan sosialisasi bahwa bahasa Arab itu penting dikaji dan dikuasai sebagai bahasa studi Islam dan ilmu pengetahuan. Diperlukan juga upaya standarisasi kemampuan bahasa Arab bagi calon mahasiswa maupun calon lulusan Perguruan Tinggi (misalnya dengan TOAFL), sehingga mereka memiliki standar kompetensi dalam berbahasa Arab. Penciptaan lingkungan berbahasa Arab (dengan keteladanan dosen dalam berbahasa Arab sebagai bahasa akademik/ perkuliahan) penting digalakkan. Para dosen juga perlu membiasakan menulis karya ilmiah dalam bahasa Arab, sehingga dikenal oleh dunia luar, khususnya dunia Arab. Pemanfaatan teknologi informasi dan komunikasi yang canggih, khususnya dalam bidang teknologi dan multimedia pendidikan bahasa Arab juga perlu dipikirkan bersama. Intinya: aktualisasi peran bahasa Arab harus dibarengi dengan reformasi sistem pendidikan bahasa Arab secara terpadu, integral dan berkelanjutan, mulai dari tingkat dasar, menengah hingga perguruan tinggi. Dengan demikian, bahasa Arab insya Allah akan menjadi bahasa yang menarik, terutama dalam posisinya sebagai bahasa pendidikan dan kebudayaan. Umat Islam, baik kalangan santri maupun nonsantri, dipandang perlu memberikan apresiasi yang memadai terhadap pengembangan dan sosialisasi bahasa Arab di Indonesia.

Apresiasi yang antara lain perlu diaktualisasikan adalah intensifikasi dan ekstensifikasi jam belajar bahasa Arab di madrasah-madrasah maupun sekolahsekolah, bahkan perguruan tinggi Islam seperti UIN, IAIN, STAIN, Perguruan Tinggi Negeri di bawah naungan Kemendikbud dan PTAIS lainnya. Berbagai institusi pendidikan dan lembaga pemerintahan lainnya, seperti Akademi Pariwisata, Akademi Seni dan Budaya, Departemen Pariwisata dan Budaya, Departemen Luar Negeri dan sebagainya sudah saatnya "melirik" pangsa pasar negara-negara Arab yang secara ideologis dan religius memiliki kesamaan dengan bangsa kita yang mayoritas beragama Islam, dan secara ekonomis, mereka lebih potensial dan kaya. Promosi dan diplomasi kebudayaan ke berbagai negara Timur Tengah tampaknya masih minim. Karena itu, intensifikasi kerjasama antarnegara dan perwakilan Indonesia di Timur Tengah perlu dikembangkan dan dioptimalisasikan.

\section{Simpulan}

Dari uraian terdahulu, dapat disimpulkan bahwa peran bahasa Arab sebagai bahasa agama, bahasa integrasi dunia Arab (dan Islam), dan bahasa resmi PBB, tetap penting, tidak hanya dalam pengembangan kajian keislaman tetapi juga dalam pengembangan ilmu pengetahuan dan peradaban. Bahasa Arab dan peradaban 
Islam sepanjang sejarahnya tidak dapat dipisahkan, bagaikan dua sisi dari mata uang. Di satu sisi bahasa Arab bisa berkembang maju karena al-Qur'an, dan di sisi lain, bahasa Arab perlu dikembangkan sebagai ilmu karena dibutuhkan untuk melayani kajian al-Qur'an. Bahkan para qurrâ' adalah juga para ahli bahasa. Ilmuilmu bahasa Arab dan keislaman bisa berkembang, antara lain, karena adanya inspirasi dan motivasi dari al-Qur'an yang berbahasa Arab.

Ketika Islam berkembang luas dan bersentuhan dengan peradaban lain, bahasa Arab berperan sebagai jembatan penghubung keilmuan melalui gerakan penerjemahan. Gerakan ini mendapat momentum yang tepat, tidak hanya dari kalangan ulama, tetapi juga dukungan politik dan finansial dari umara, sehingga sinergi kekuasaan dan pengetahuan menjelma menjadi sebuah kekuatan yang dahsyat dalam pengembangan ilmu pengetahuan dan peradaban Islam. Gerakan penerjamahan karya-karya Yunani, India, dan Persia ke dalam bahasa Arab, lalu ditindaklajuti dalam bentuk penelitian dan pengembangan karya-karya kreatif dan inovatif dari ulama Islam yang juga berkolaborasi dengan ilmuwan non-Muslim, mejadikan bahasa Arab sebagai bahasa ilmu dan peradaban.

Bahasa Arab ke depan diprediksi dapat berperan lebih optimal lagi jika lembaga pendidikan Islam dapat bersinergi dengan kekuasaan dalam memantapkan perannya sebagai bahasa diplomasi, bahasa edukasi, dan bahasa komunikasi dalam berbagai bidang. Karena itu, diperlukan adanya inovasi sistem pendidikan bahasa Arab yang lebih dari sekadar PAIKEM, misalnya pembelajaran bahasa Arab berbasis riset, berbasis budaya, berbasis penciptaan lingkungan berbahasa komunikatif dan produktif. Peran bahasa Arab sebagai bahasa edukasi dan studi, termasuk sebagai standarisasi, perlu diaktualisasikan dengan mendinamisasikan berbagai kegiatan akademik yang kreatif dan inovatif.

Selain itu, peran IMLA (Ittihâd Mudarrisî al-Lughah al-'Arabiyyah) ke depan, diharapkan bisa seperti ma'jâmi al-Lughah al-'Arabiyyah di beberapa negara Timur Tengah, seperti Mesir, Saudi Arabia, Yordania, Suriah dan Irak; bukan sekadar menjadi organisasi asosiasi profesi, melaimkan juga menjadi institusi ilmiah dan intelektual yang dinamis dan produktif, menjadi referensi dalam standarisasi sumber belajar bahasa Arab, standarisasi evaluasi dan tes bahasa Arab, dan bahkan pusat sertifikasi guru bahasa Arab, penerjemah bahasa Arab, dan calon diplomat yang akan ditugaskan di negara-negara Arab. 


\section{Referensi}

Amin, Samsul Munir. 2015. Sejarah Peradaban Islam. Jakarta: Amzah.

Al-'Isysy, Yûsuf. 1989. Al-Dawlah al-Umawiyyah wa al-Ahdâts al-Târîkhiyyah allatî Sabaqathâ wa Mahhadât lahâ ibtidân min Fitnah Utsmân. Damaskus:

Dâr al-Fikr.

Al-Shaghir, Abd al-Majid. 2010. Al-Ma'rifah wa al-Sulthah fî al-Tajribah alIslâmiyyah. Kairo: al-Hai'ah al-Mishriyyah al-'Ammah.

Al-Syaibani, Umar al-Taumi. 1992 . Ishâmât al-Muslimîn fi al-'Ulûm, dalam Jurnal al-Da'wah al-Islâmiyyah. Tripoli-Libia Edisi IX.

Arief, Armai (ed.). 2004. Sejarah Pertumbuhan dan Perkembangan Lembaga-

lembaga Pendidikan Islam Klasik. Jakarta: UIN Jakarta Press.

Asroah, Hanun. 1999. Sejarah Pendidikan Islam. Jakarta: Logos.

Bakri, Syamsul. 2011. Peta Sejarah Peradaban Islam. Yogyakarta: Fajar Media Press.

Chejne, Anwar G.1996. Bahasa Arab dan Peranannya dalam Sejarah, The Arabic Language: Its Role in History, terj. Aliudin Mahjudin. Jakarta: Pusat Pembinaan dan Pengembangan Bahasa.

Efendy, A. Fuad. 2009. Metodologi Pembelajaran Bahasa Arab. Malang: Misykat. Fajar, Abdullah. 1996. Peradaban dan Pendidikan Islam. Jakarta: Rajawali Press. Fuadi, Imam. 2011. Sejarah Peradaban Islam. Yogyakarta: Teras.

Hallâq, Husain. 1988. Târîkh al-Hadhârah al-Islâmiyyah. Kairo: Dâr al-Kutub alIslâmiyya.

Hijazi, Mahmud Fahmi. 1998. Al-Lughah al-'Arabiyyah fî al-'Ashr al-Hadîts: Qadhâyâ wa Musykilât. Kairo: Dar Quba'.

Lapidus, Ira M. 1999. Sejarah Sosial Umat Islam. terj. Ghufron M. Mas'adi. Jakarta: Rajawali Press.

Mas’ud, Jibran. 2001. Al-‘Arabiyyah al-Fushhâ: Sya'latun lâ Tanthafi'. Beirut: Bait al-Hikmah.

Nakosteen, Mehdi. 1996. Kontribusi Islam atas Dunia Intelektual Barat. terjemahan,. Surabaya: Risalah Gusti.

Qadir, C.A. 1989. Filsafat dan Ilmu Pengetahuan dalam Islam. terj. dari Philosophy and Science in the Islamic World oleh Hasan Basari. Jakarta: Obor Indonesia.

Widodo, Ardi Sembodo. 2014. "Kata Pengantar Buku” dalam Rivany Philanthrpy (Ed.), Sejarah Pendidikan Bahasa Arab di Dalam dan Luar Negeri. Yogyakarta: Maktabah Mandiri. 